\title{
VARIABILITY OF LINEARLY EVALUATED TRAITS OF TYPE OF SIMMENTAL BULL DAMS **
}

\author{
V. Pantelic ${ }^{1 *}$, Z. Skalicki, ${ }^{2}$ M. M. Petrović ${ }^{1}$, S. Aleksić ${ }^{1}$, \\ B. Miščević ${ }^{3}$, D. Ostojić-Andrić ${ }^{1}$ \\ ${ }^{1}$ Institute for Animal Husbandry, Belgrade-Zemun, Serbia \\ ${ }^{2}$ Faculty of Agriculture, Zemun, Serbia \\ ${ }^{3}$ Faculty of Biofarming, Sombor, Serbia \\ *Corresponding author, e-mail: vladapantelic.izs@gmail.com \\ **Original scientific paper. Financed by the Ministry of Science of Republic of Serbia, \\ Project TR- 6858B
}

\begin{abstract}
One of the important factors of successful milk production is group of secondary traits: health, longevity, type and milking traits. These traits have become increasingly significant. In order for productive life of cows used in production of milk to be as long and as successful as possible, special attention must be directed to traits of body type and constitution. In selection of cows into the category of bull dams all heads are measured exterior traits, and evaluated linearly for traits of type or body frame, body muscular characteristics/muscularity, form (appearance) and udder according to Regulation on method of evaluation of traits of breeding livestock (Official journal of RS, No. 21,1996).

The effects of rearing region and year of measuring, i.e. evaluating were analyzed in detail using the Least Squares Method (Harvey 1987).

Average values of linear evaluations of investigated heads obtained by method of Least Squares were: body frame 7,85; muscularity 7,74; form 7,66; udder 7,62.

The effect of region on linear evaluation was highly significant $(\mathrm{P}<0,01)$. Evaluation year also influenced highly significantly $(\mathrm{P}<0,01)$ obtained evaluation result for form, significantly $(\mathrm{P}<0,05)$ obtained evaluation result for body frame and muscularity, but no effect was established on evaluation result for udder.
\end{abstract}

Key words: linear evaluation, bull dams, Simmental breed, region, year 


\section{Introduction and literature review}

Linear evaluation of the type was introduced by the Programme of livestock production improvement measures as obligatory/mandatory measure in cattle selection in our country. It is desirable to evaluate cows in the first lactation from 30 to 150 days subsequent to calving because of the capacity and activity of udder during this period and assumption that the genetic basis is surer during this period for evaluation and that the effect of outside factors is insignificant (Pantelić, 2004).

Regulation anticipates individual numerical evaluation of female heads for traits of type, muscularity, form and udder. This numerical, i.e. linear evaluation includes evaluating of every anticipated trait in its biological extremes, according to scale from 1 to 9 in evaluation chart, however, it should be pointed out that nine (9) as the highest score is not the best score for each trait, since, for instance, average score (5) for position of croup, position of hind legs, back firmness, and length and thickness of teats is the best.

In linear evaluation of cattle we can not focus on searching for exterior faults, but rather view the animal as a functional entirety which will produce high quality product, produce it over long period of time and this production will be economically efficient.

Evaluation of the animal's exterior is carried out based on the knowledge of structure and function of certain organs and major relations between certain body parts. Phenotypic correlations between form and production characteristics are positive but relatively low, therefore, selection from the production aspect cannot be based on evaluation of the exterior of cattle.

Hereditary faults should be treated especially strict, and all heads with degenerative anomalies should be excluded from the herd (anomalies of the mammary gland, genital tract, hernia, weak hind legs, blindness, etc.).

Latinovic (1985) was the first researcher in our country who carried out linear evaluation of the type of Black and White and Holstein-Friesian cattle on farms of $\mathrm{PK} »$ Beograd «. Cattle were evaluated using the evaluation scale from 1-9. Fourteen traits were evaluated and 9 undesired occurrences registered. The lowest average score in Black and White cows was determined in width of rear udder quarters 3,46 , whereas the highest average score was determined in pelvis position 5,82. In Holstein-Friesian cattle, score for type varied from 4,59 for teat position to 5,79 for height of rear quarters.

Živanović (2002) investigated the variability of linearly evaluated traits 
of type and milk yield of first calving cows of Black and White breed on sample of 2.976 cows reared on farms of PK »Beograd«. Linear evaluation of type was performed during the period from 30 to 150 days from the beginning of lactation. Evaluation system included 14 traits, of which 6 were traits of body development and 8 udder traits. Scores were within the scale from 1 to 9 . Average values of obtained evaluation results were in the interval from 5,28 to 7,15 , for body development and from 5,06 to 7,02 for udder traits.

Stojic et al. (2002) stated that linear evaluation of the type of Black and White first calving cows has been carried out in past years on farms of PK »Beograd«. Fourteen traits are evaluated, of which 6 are traits of body development and 8 udder traits. Evaluation scale with score from 1 to 9 is used. Average demonstration of trait is scored 5. For 4 traits: position of pelvis and hind legs, balance of udder and size of teats, this is the best score. For remaining traits, average values should be as high as possible.

In the Instruction for linear evaluation of type and cattle condition Pantelic et al. (2005) state that linear evaluation is used also in selection of breeding animals when it should be taken into consideration that heads which will be parents compensate mutually disadvantages in exterior.

Disadvantages in type traits lead to lower production, poor health condition and premature culling of cows from the herd. Including of linear evaluation of type in evaluation of breeding value of cows contributes to reliability of the breeding value evaluation which reflects positively on total effects of selection and success of the production (Pantelic et al. 2007).

\section{Material and methods}

This research included 292 Simmental cows selected into category of bull dams on the territory of Republic of Serbia. Selection of cows into the herd of bull dams was carried out after the first lactation, i.e. based on subsequent lactations. Distribution of bull dams was carried out on 7 regions, i.e. breeding areas where heads were reared, and 9 groups based on the year of their measuring and evaluation.

Breeding regions and number of selected bull dams in them were as follows:

1. Belgrade region (municipality of Mladenovac) -27

2. Podunavski - Danube region (municipality of Smederevska Palanka) -88

3. Braničevo region (municipality of Požarevac) -50 
4. Timok region (municipality of Zaječar) -24

5. Kolubara region (municipality of Valjevo) -55

6. Pomoravlje-Rasina region (municipalities of Jagodina, Kraljevo and Kruševac) -32

7. Zlatibor region (municipality of Užice) - 16

Investigation included following linear evaluations:

- $\quad$ Type or frame

- Muscularity

- Form or appearance

- Udder

Analysis of the effect of paragenetic factors on investigated linear scores for type was carried out using method of Least Squares (Harvey 1987), fixed model:

$$
\mathrm{Y} i j k=\mu+\mathrm{R}_{l+} \mathrm{G} j+\mathrm{e} i j_{k}
$$

where:

$\mathrm{Yi}_{l k}=$ demonstration of investigated trait in $k$ cow, evaluated in $i$ region, in $j$ year.

$\mu \quad=$ general average

$\mathrm{R}_{l} \quad=$ fixed effect of $l$ region

$\mathrm{G} j \quad=$ fixed effect of $j$ evaluation year

eijk $=$ random error.

\section{Results and Discussion}

Type or frame. Evaluation of type or body frame is based on height to withers, body length, breast depth and body width (Pantelić et al. 2006). Using the method of Least Squares general average of linear score for type was obtained $-7,85$.

Regions had statistically highly significant effect on score for body frame of heads $(\mathrm{P}<0,01)$. The highest score was given to heads on the territory of municipality Zaječar - 8,18, and bull dams selected on the territory of municipality of Valjevo had the lowest score 7,40.

The effect of the year of evaluation was statistically significant $(\mathrm{P}<0,05)$. Interval of variation in evaluation years was from 7,54 in year 1998 to 8,28 in 2003 . 
Table 1. General average, mean values of least squares and their errors, and significance of the effects of breeding area on linear scores

\begin{tabular}{|c|c|c|c|c|c|c|c|c|}
\hline Regions & Type & Slsm & Musc. & Slsm & Form & Slsm & Udder & Slsm \\
\hline $\begin{array}{l}\text { General } \\
\text { average }\end{array}$ & \multicolumn{2}{|c|}{7.85} & \multicolumn{2}{|c|}{7.74} & \multicolumn{2}{|c|}{7.66} & \multicolumn{2}{|c|}{7.62} \\
\hline 1. & 7.61 & 0.13 & 7.43 & 0.13 & 7.60 & 0.13 & 7.62 & 0.13 \\
\hline 2. & 8.04 & 0.10 & 7.87 & 0.09 & 7.78 & 0.09 & 7.63 & 0.09 \\
\hline 3. & 7.64 & 0.11 & 7.44 & 0.10 & 7.34 & 0.10 & 7.37 & 0.10 \\
\hline 4 & 8.18 & 0.14 & 7.99 & 0.14 & 7.96 & 0.14 & 7.67 & 0.14 \\
\hline 5. & 7.40 & 0.13 & 7.44 & 0.13 & 7.42 & 0.13 & 7.33 & 0.13 \\
\hline 6. & 7.92 & 0.13 & 7.79 & 0.13 & 7.71 & 0.13 & 7.90 & 0.13 \\
\hline 7. & 8.15 & 0.17 & 8.19 & 0.17 & 7.84 & 0.17 & 7.83 & 0.17 \\
\hline F-test & \multicolumn{2}{|c|}{$f_{t a b}=5.323^{* *}$} & \multicolumn{2}{|c|}{$f_{t a b}=5.540^{* *}$} & \multicolumn{2}{|c|}{$f_{t a b}=3.680^{* *}$} & \multicolumn{2}{|c|}{$f_{t a b}=3.831 * *$} \\
\hline
\end{tabular}

$$
\text { N.S }-\mathrm{P}>0.05 ; *-\mathrm{P}<0.05 ; * *-\mathrm{P}<0.01
$$

Table 2. General average, mean values of least squares and their errors, and significance of the effects of the evaluation year on linear score

\begin{tabular}{|c|c|c|c|c|c|c|c|c|}
\hline Year & Type & Slsm & Musc. & Slsm & Form & Slsm & Udder & Slsm \\
\hline $\begin{array}{l}\text { General } \\
\text { average }\end{array}$ & \multicolumn{2}{|c|}{7.85} & \multicolumn{2}{|c|}{7.74} & \multicolumn{2}{|c|}{7.66} & \multicolumn{2}{|c|}{7.62} \\
\hline 1995 & 8.06 & 0.26 & 8.09 & 0.25 & 7.63 & 0.25 & 7.49 & 0.25 \\
\hline 1996 & 7.57 & 0.22 & 7.50 & 0.22 & 7.40 & 0.22 & 7.60 & 0.22 \\
\hline 1997 & 7.67 & 0.16 & 7.61 & 0.16 & 7.43 & 0.16 & 7.70 & 0.16 \\
\hline 1998 & 7.54 & 0.20 & 7.37 & 0.20 & 7.42 & 0.20 & 7.50 & 0.20 \\
\hline 1999 & 7.95 & 0.15 & 7.55 & 0.15 & 7.74 & 0.14 & 7.57 & 0.14 \\
\hline 2000 & 7.75 & 0.12 & 7.71 & 0.11 & 7.67 & 0.11 & 7.48 & 0.11 \\
\hline 2001 & 7.80 & 0.08 & 7.73 & 0.08 & 7.64 & 0.08 & 7.55 & 0.08 \\
\hline 2002 & 8.01 & 0.08 & 7.86 & 0.08 & 7.82 & 0.08 & 7.78 & 0.08 \\
\hline 2003 & 8.28 & 0.12 & 8.19 & 0.11 & 8.22 & 0.11 & 7.93 & 0.11 \\
\hline F-test & \multicolumn{2}{|c|}{$f_{t a b}=2.376^{*}$} & \multicolumn{2}{|c|}{$f_{t a b}=2.613^{*}$} & \multicolumn{2}{|c|}{$f_{t a b}=2.787 * *$} & \multicolumn{2}{|c|}{$f_{t a b}=1.476^{n s}$} \\
\hline
\end{tabular}


Muscularity. Development of the musculature of individual heads, i.e. muscularity is evaluated based on the presence of muscle tissue in the rear part of the body, i.e. rounds and croup. Regions had highly significant effect $(\mathrm{P}<0,01)$ on muscularity score, and variation interval was from 7,43 (Belgrade region) to 8,19 (Zlatibor region). This statement indicates high flexibility of Simmental breed in production of milk and meat. Bull dams from the territory of municipality of Mladenovac had high milk yield and the lowest muscularity, contrary to cattle on the territory of municipality of Užice which had the lowest milk production and the highest muscularity.

Evaluating year had statistically significant effect $(\mathrm{P}<0,05)$ on score for muscularity. In year 1998 the highest negative deviation of $-0,36$ was determined, and in 2003 the highest positive deviation 0,46.

Form or appearance. The following traits were evaluated: connection of shoulders, back firmness and line, position of croup and hind legs. General average of linear score for form or appearance was obtained by method of least Squares - 7,66.

The effect of breeding region was highly significant $(\mathrm{P}<0,01)$. Interval of variation was from 7,34 in Braničevo region to 7,96 in Timok region.

Year of evaluation had highly significant effect on linear score for form. Heads with the best score were evaluated in $2003-8,22$, whereas the lowest score was obtained in $1996-7,40$.

Udder. Evaluation of udder is based on observations of following traits: connection of the front udder, length of udder, connection of udder, position, length and shape of teats. General average of linear score for udder in bull dams of Simmental breed was 7,62.

The effect of region was highly significant $(\mathrm{P}<0,01)$. The best score for udder was determined in bull dams on the territory of municipalities of Jagodina, Kraljevo and Kruševac 7,90, and the lowest score in bull dams on the territory of the municipality Valjevo, 7,33.

Average values of udder score varied insignificantly in years of evaluation $(\mathrm{P}>0,05)$.

\section{Conclusion}

In order for productive life of cows used for milk production to be long and productive, special attention must be directed towards traits of type and constitution. Disadvantages in traits of type lead to lower production, poor health condition and premature exclusion from the herd.

Including of linear evaluation of type in evaluation of breeding value of 
cows contributes to reliability of the breeding value evaluation which reflects positively on total effects of selection and success of the production

Average values of linear score in investigated heads were obtained by method of Least Squares: body frame 7,85; muscularity 7,74; form 7,66; udder 7,62.

The effect of region on linear score was very significant $(\mathrm{P}<0,01)$. Year of evaluation had highly significant effect $(\mathrm{P}<0,01)$ on score for form, significantly $(\mathrm{P}<0,05)$ on score for body frame and muscularity, and no effect on score for udder.

Visual evaluation and knowledge of milk characteristics of cows are preliminary indicators of milk production, and partially also of longevity and reproductive ability of the head of cattle, which is very important from the aspect of economical efficiency in dairy production.

\title{
VARIJABILNOST LINEARNO OCENJENIH OSOBINA TIPA BIKOVSKIH MAJKI SIMENTALSKE RASE
}

\author{
V. Pantelić, Z. Skalicki, M. M. Petrović, S. Aleksić, B. Miščević, \\ D. Ostojić-Andrić
}

\section{Rezime}

Da bi produktivni život krava usmerenih za proizvodnju mleka bio što duži i uspešniji posebnu pažnju treba posvetiti osobinama tipa i konstitucije. Nedostaci u osobinama tipa dovode do slabije proizvodnje, lošeg zdravstvenog stanja i preranog isključenja krava iz stada. Uključivanje linearne ocene tipa u oceni priplodne vrednosti krava doprinosi pouzdanosti ocene priplodne vrednosti što se pozitivno odražava na ukupne efekte selekcije i uspešnosti proizvodnje.

Pri izboru krava u kategoriju bikovskih majki sva grla su eksterijerno izmerene i linearno ocenjene za okvir, muskuloznost, formu (izgled) i vime u skladu sa Pravilnikom o načinu ispitivanja svojstava priplodne stoke (Službeni glasnik RS br. 21 iz 1996.godine).

$\mathrm{Na}$ ispitivane linearne ocene detaljno su ispitani uticaji odgajivačkog područja i godine merenja, korišćenjem Metoda najmanjih kvadrata (Harvey 1987 ). 
Prosečne vrednosti linearne ocene ispitivanih grla dobijene metodom najmanjih kvadrata su: okvir grla 7,85; muskuloznost 7,74; forma 7,66; vime 7,62 .

Uticaj regiona na linearne ocene bio je vrlo značajan $(\mathrm{P}<0,01)$. Godina ocenjivanja je visoko značajno uticala $(\mathrm{P}<0,01)$ na ocenu forme, značajno $(\mathrm{P}<0,05)$ na ocenu okvira i muskuloznosti, a na ocenu vimena nije imala značaj.

\section{References}

HARVEY, W.R. (1987): Mixed model Least Squares and maximum Likelihood Computer Program. User, s Guiede for LSML MW and MIX MDL.

LATINOVIĆ, D. (1985): Kvantitativno genetsko ocenjivanje telesne razvijenosti tipa krava u populacijama evropskih crno-belih i Holštajnfrizijskih goveda. Doktorska disertacija. Poljoprivredni fakultet, Beograd.

PANTELIĆ, V. (2004): Fenotipska varijabilnost proizvodnih i reproduktivnih osobina bikovskih majki simentalske rase. Magistarska teza. Poljoprivredni fakultet, Beograd.

PANTELIĆ, V., PETROVIĆ, M.M., STOJIĆ, P (2005): Uputstvo za linearno ocenjivanje tipa i kondicije goveda. Institut za stočarstvo, BeogradZemun.

PANTELIĆ, V., SKALICKI Z., PETROVIĆ, M.M., ALEKSIĆ, S., MIŠČEVIĆ, B., OSTOJIĆ, D. (2006): Telesna razvijenost bikovskih majki simentalske rase. Biotehnologija u stočarstvu 22 (3-4), p. 23-32.

PANTELIĆ, V., SKALICKI Z., PETROVIĆ, M.M., LATINOVIĆ, D., ALEKSIĆ, S., MIŠČEVIĆ, B., OSTOJIĆ, D. (2007): Linearno ocenjivanje bikovskih majki simentalske rase. Savremena poljoprivreda 1-2, p. 49-53.

STOJIĆ, P., ŽIVANOVIĆ LJ., BESKOROVAJNI R., NIKOLIĆ, R., MARKOVIĆ, N. (2002): Značaj linearne ocene tipa u odgajivačkim programima mlečnih goveda. Biotehnologija u stočarstvu 18 (5-6) p. 31-35. SLUŽBENI GLASNIK RS (1996): Pravilnik o načinu ispitivanja svojstava priplodne stoke i o uslovima proizvodnje i transporta živine. 693-694. Beograd.

ŽIVANOVIĆ, LJ. (2002): Varijabilnost linearno ocenjenih osobina tipa i mlečnosti prvotelki crno-bele rase. Magistarska teza. Poljoprivredni fakultet, Beograd. 